Management international

International Management

Gestiòn Internacional

\title{
Appropriation under Low Intellectual Property Regimes: The Role of Communities in the Online Alternative Adult Entertainment Industry
}

Appropriation dans un régime de propriété intellectuelle faible : le rôle des communautés dans l'industrie du divertissement pour adultes alternative en ligne

\section{La apropiación en un régimen de baja protección de la propiedad intelectual: el papel de las comunidades en la industria del entretenimiento para adultos alternativa en línea}

Kim-Marlène LE et Julien PÉNIN

Volume 21, numéro 3, printemps 2017

Communautés et réseaux de pratique : organisations innovantes et globalisation des connaissances

Communities and networks of practice: Innovative organizations and knowledge globalization

Comunidades y redes de práctica: Las organizaciones innovadoras Y

la globalización del conocimiento

URI : https://id.erudit.org/iderudit/1052766ar

DOI : https://doi.org/10.7202/1052766ar

Aller au sommaire du numéro

Éditeur(s)

HEC Montréal

Université Paris Dauphine

ISSN

1206-1697 (imprimé)

1918-9222 (numérique)

Découvrir la revue

Citer cet article

LE, K.-M. \& PÉNIN, J. (2017). Appropriation under Low Intellectual Property Regimes: The Role of Communities in the Online Alternative Adult Entertainment Industry. Management international / International Management / Gestiòn Internacional, 21(3), 71-80. https://doi.org/10.7202/1052766ar

\section{Résumé de l'article}

Darling (2014) a montré que l'industrie pour adultes est un nouveau cas de régime de propriété intellectuelle faible, où la protection formelle contre le piratage des contenus est largement inefficace. Dans cet article, nous nous basons sur le cas de la pornographie alternative afin d'étudier les mécanismes incitatifs à la création de contenus. En effet, les communautés d'utilisateurs aident les fournisseurs à absorber les coûts fixes associés à la production et la distribution de contenus. Nous concluons que ces communautés complètent les stratégies d'appropriation, bien qu'elles ne peuvent résoudre à elles-seules le problème d'incitations économiques dans la pornographie en ligne.
Tous droits réservés (C) Management international / International Management / Gestión Internacional, 2017
Ce document est protégé par la loi sur le droit d'auteur. L’utilisation des services d’Érudit (y compris la reproduction) est assujettie à sa politique d'utilisation que vous pouvez consulter en ligne.

https://apropos.erudit.org/fr/usagers/politique-dutilisation/ 


\section{Appropriation under Low Intellectual Property Regimes: The Role of Communities in the Online Alternative Adult Entertainment Industry ${ }^{1}$}

\section{Appropriation dans un régime de propriété intellectuelle faible : le rôle des communautés dans l'industrie du divertissement pour adultes alternative en ligne}

\section{La apropiación en un régimen de baja protección de la propiedad intelectual: el papel de las comunidades en la industria del entretenimiento para adultos alternativa en línea}

\author{
KIM-MARLÈNE LE \\ Université de Strasbourg, CNRS, BETA UMR 7522, \\ F-67000 Strasbourg, France \\ Scuola Superiore Sant'Anna, Laboratory of Economics \\ and Management, I-56127 Pisa, Italy
}

\author{
JULIEN PÉNIN \\ Université de Strasbourg, CNRS, BETA UMR 7522, \\ F-67000 Strasbourg, France
}

\section{ABSTRACT}

The online adult entertainment industry, as Darling (2014) showed, is a new case of low intellectual property regime, i.e. largely inefficient in preventing the massive copying of content. In this paper, we focus on alternative pornography and explore the mechanisms which contribute to the creation of pornographic content. We argue that user communities help content providers to absorb sunk costs associated with content production and distribution. Our main conclusion is that, although user communities cannot solve alone the incentive failure in online pornography, they complement and reinforce strategies which enable content producers to earn revenues from vulnerable copyrighted works.

Keywords: intellectual property rights, communities, low IP regime, online adult entertainment industry, alternative pornography

\section{RÉSUMÉ}

Darling (2014) a montré que l'industrie pour adultes est un nouveau cas de régime de propriété intellectuelle faible, où la protection formelle contre le piratage des contenus est largement inefficace. Dans cet article, nous nous basons sur le cas de la pornographie alternative afin d'étudier les mécanismes incitatifs à la création de contenus. En effet, les communautés d'utilisateurs aident les fournisseurs à absorber les coûts fixes associés à la production et la distribution de contenus. Nous concluons que ces communautés complètent les stratégies d'appropriation, bien qu'elles ne peuvent résoudre à elles-seules le problème d'incitations économiques dans la pornographie en ligne.

Mots-Clés : droits de propriété intellectuelle, communautés, régime de propriété intellectuel faible, industrie pour adulte en ligne, pornographie alternative.

\section{RESUMEN}

Para Darling (2014), la industria para adultos es un nuevo caso de régimen de baja protección de la propiedad intelectual (un régimen que es en gran medida ineficaz contra la piratería). En este estudio exploramos cómo la pornografía alternativa contribuye a la creación de contenido. Sostenemos que las comunidades de usuarios permiten a los productores absorber los costes irrecuperables asociados a la explotación de contenidos. Concluímos que, aunque las comunidades no pueden resolver la ausencia de incentivos en la pornografía en línea, éstas complementan estrategias que permiten a los productores la obtención de ingresos de la explotación de obras protegidas.

Palabras Clave: derechos de propiedad intelectual, comunidades, régimen de baja protección de la propiedad intelectual, industria del entretenimiento para adultos en línea, pornografía alternativa. n a context where the Internet and digitization make it inc-
reasingly difficult to enforce intellectual property rights (IPR
in the following) such as copyrights and patents, the issue of
appropriation mechanisms, i.e. how actors can appropriate
a share of the value that they have contributed to create, is central in many sectors. If new creations are not protected by IPR, what are the incentives to invest in developing them? ${ }^{2}$ One important lesson of this literature is that IPR may not always be absolutely necessary in order to provide actors with a minimum level of incentives to innovate (Raustiala and Sprigman, 2012).

1. Acknowledgements: We are very grateful to Stéphane and Viviane Morey for welcoming us at their festival and to the anonymous interviewees for their time and insights. We would also like to thank our peers for their valuable comments on our study. We are grateful to Jean-Yves Bart for proof-reading this document. We would like to thank the anonymous referees for their valuable and constructive evaluation on an earlier draft of this paper.

2. This question is sometimes referred as to the problem of IP without IP, i.e. "information production without intellectual protection" (Darling, 2014). Sectors such as gourmet cuisine (Fauchart and von Hippel, 2008; Di Stefano et al., 2013), magic (Loshin, 2007), tattoos (Perzanowski, 2013), stand-up comedy (Oliar and Sprigman, 2008), fashion (Raustiala and Sprigman, 2006), open source software (Lerner and Tirole, 2001; Pénin, 2011) were identified as being such low IP regimes in which innovation nevertheless exists and is sometimes vibrant thanks to alternative value appropriation mechanisms.

3. Whether or not this level of incentives is optimal is another matter beyond the purview of this paper. We observe that, under low IP regimes, innovative and creative activities persist. Whether or not the level of this activity is higher or lower with formal IPR, although obviously a critical question, will not be addressed here. 
Alternative elements, such as informal norms, complementary assets (trademark for instance), offering a live experience rather than a product, can sometimes enable innovators to generate profits out of their innovations even when the latter are not protected by formal IPR. ${ }^{4}$

In this paper we focus on another case of low IP regime, namely the online adult entertainment industry (or online pornography). This industry was developed with the introduction of the Internet and combines several goods and services (Zook, 2003): pornographic content (e.g. audio, video, pictures...), dating sites, sexual services (escorts, erotic dancing, prostitution), and accessories (clothing, sex-toys). In our analysis we focus on alternative (feminist) pornography, where the dynamics of creation and valorization might differ from mainstream production. Furthermore, we concentrate mostly on the sale of digital pornographic content even though we are aware that it is strongly (and increasingly) related to the other businesses such as escorting, dating sites and accessories.

The case of online pornography appears typical of industries that do not seem to need IPR in order to be innovative (Boldrin and Levine, 2008). Indeed, for many reasons, legal, technical but also moral, copyright infringement has become both common and pervasive in this industry ${ }^{5}$. Yet, despite this apparent appropriation failure, the production of original content has not ceased (even though, and this is an important question which is still open, its nature may have evolved over the last few decades). As legal and technical means to protect digital content from online piracy often proved inefficient, firms have had to adapt. They have done so, first, by reorganizing the industry through mergers and acquisitions and second, by developing innovative ways to make their business model sustainable.

In a pioneering study, Darling (2014) relied on in-depth qualitative interviews with mainstream content producers in the USA to show that producers have increasingly moved towards the distribution of contents because this enabled them not only to sell content (which is less profitable because it is easy to copy), but also to sell a live experience and a convenient access, services which are more difficult to copy. In other words, Darling stresses one fundamental development in the online adult entertainment industry: sources of competitive advantage for producers are shifting from production to distribution. However, this analysis missed an important element by focusing on "big players" and mainstream markets, failing to detail how, the role of user communities in the creation and appropriation of value in online pornography ${ }^{6}$ is vital for "entrepreneurs" (see table 1), especially in niche markets.

The aim of this paper is to complement Darling's analysis, which essentially addresses the mainstream porn market, by emphasizing, in addition to live experience and convenience, the role of user communities (defined as groups of people sharing the same interest and working regularly to create specific knowledge and which are regulated by a set of social norms) (Cohendet et al., 2006) in enabling online content producers to benefit from their new creation in niche markets such as alternative pornography. To do so, we first base ourselves on the abundant literature on knowledge communities, which stresses the role of the communities in order to produce, store and distribute knowledge (Amin and Roberts, 2008; Lave and Wenger, 1991; Cohendet et al., 2003; and others) to analyze the case of alternative pornography. Second, we zoom in on a particular community of alternative porn festival-goers in a series of interviews.

Our analysis shows that in the case of online pornography, user communities can help to absorb some of the sunk costs linked to media production and distribution. They can contribute to structuring a demand for particular niche contents, to the testing of new content or devices, to their advertising and diffusion, to increasing the value of produced contents by adding comments, complementary information, enabling real life meeting and dating, etc. Our main conclusion is that, although user communities cannot alone solve the appropriation failure in online pornography, they can complement other strategies which enable content producers to make money out of unprotected content.

The next section introduces the context of alternative pornography. The third discusses a mechanism for appropriation which so far has not been identified in the literature on online pornography: the involvement of user communities. The fourth displays the case of one specific festival which interacts with several communities linked to the alt-porn movement. The last section concludes.

\section{The CONTEXT OF ALTERNATIVE (FEMINIST) PORNOGRAPHY}

Alternative pornography (including feminist, queer, indie and post-porn $)^{7}$ which distinguishes itself from so-called mainstream pornography, was born at the same time as third-wave American feminism. The sex-positive or pro-porn feminist

4. As summarized by Loshin (2007) in the case of magic: "The magic community has developed a unique set of informal norms and sanctions for violators, which protect intellectual property in the absence of law. Hence, in the magic community, innovation does in fact need intellectual property. But it does not necessarily need intellectual property law".

5. As to IPR protection, the situation of adult films is therefore somewhat different from what has been observed in other low IP regimes in the sense that the problem of weak appropriability does not result from the absence of IPR but rather from the difficulty in enforcing those IPR, in particular on the Internet (Darling, 2014). A new film, regardless of its genre, can be, and usually is protected by copyright.

6. The involvement of user communities is merely mentioned in passing in Darling's study in the following quote: "Finally, companies are searching for ways to build not only virtual, but also real-life social communities around their products [...] The concept of building social interaction and community appears to work especially well for more specific content preferences, like niche markets. For example, one of the larger U.S. "fetish" producers has for some time now successfully invested in building a participatory, interactive experience around its community. The business models range from offering tours of its facilities and shooting locations to interested members of the general public, to allowing people to watch live shows in person or even participate in scenes. It is also creating a social network and live webcam community." (Darling, 2014, p.752-753)

7. The difference between the terms is historic. Feminist and queer porn are subgenres born in the late 1990s which started producing pornography as an alternative to the so-called "mainstream" pornography that dominated the market. This is why this niche is also referred to in the literature as "alternative" or "indie" porn. These semantic distinctions are not emphasized in this paper, as our interviewees did not insist on the difference between the labels themselves. 
movement appeared around 1980-1990 in the United States as an opposition to abolitionist feminists. Both groups had diverging opinions on pornography, feminine pleasure and sex labor. More recently in Europe and nowadays in France, the movement spread and female pornographers publicized their views. Some of them united to form collectives of feminist and "queer" porn directors, in an effort to participate in the creative renewal of the pornographic industry.

What we call "alternative pornography" cannot be described with precise criteria but there are a few leitmotivs. Borghi (2013) lists some of them to characterize the allegedly first post-porn performance by Annie Sprinkle ${ }^{8}$ such as a "political content and with the objective of creating social transformation" or "the involvement of spectators". ${ }^{9}$ The constitutive elements of an alt-porn content include interaction and a personal, sometimes political involvement by either the producer and/or of the consumer. The case of alt-porn is relevant to describe the existence of strong intrinsic incentives to consume and produce pornographic content in a community, be it an artistic, political community or even a community of sexual or professional practice. A couple of remarkable facts underlines further strengthen this argument.

Communities exist with their own models and norms: the alt-porn community is embedded in the inclusive tradition of human rights activist groups. These communities often try to create so-called online or offline "safe spaces" where everyone, regardless of their appearance or their sexual orientation, can feel included in the conversation. For instance, members are encouraged to advertise a "trigger warning" if they feel their addition to a given conversation can trigger negative emotional responses. In a community that promotes openness, the members feel it is important not to judge practices but nevertheless to be conscious that a practice can be offensive to another member. This often happens for example in BDSM (Bondage Discipline Sado-Masochism) communities, where pain and humiliation can be a turn on to some but traumatic to other members. Some communities, often those which are the most inclusive ones, try for example not to use terms that can be offensive to other communities (e.g. members should not use homophobic or misogynistic terms). With the Internet, these spaces for exchanging on a diversity of subjects, which are more or less closely linked with alternative pornography, have multiplied; and so have the opportunities for learning and creating along with them.

As a consequence, more and more female entrepreneurs and directors openly operate in the porn sector. Erika Lust's recent success story, among others, has inspired aspiring fellow feminist and post-pornographers to produce adult content with the aim of actually changing pornography, but also in some cases as a business opportunity. This trend is a particularly interesting phenomenon to study, because it appears to be a sign of the democratization of pornography.

\section{The role of user communities in the production of online alternative pornography}

\section{Actors in the online pornography industry}

Schematically, three types of actors are usually identified in the online pornographic industry (Table 1). First, yesterday's leaders (who we also call "historic" players) were able to remain household names in the adult industry. These companies, like Hustler, Playboy, or Dorcel in France, founded on traditional content and distribution channels (long feature films, quasi cinematographic production), count on their brand name to keep their market share. The historical companies can count on their capital (i.e. resources accumulated over their leadership period) to branch out into side markets: dating, news, lifestyle, sex-toys and events. As far as the commercialization of their video contents is concerned, their strategy is to develop curated content that meets their customers' expectations.

Second, "entrepreneurs" are smaller entities, often a selfemployed person or an unpaid volunteer, who provide homemade or highly curated content. These entrepreneurs can count on the very low cost of entry, which consists at least in an Internet connection (plus a camera for performers) to provide content either in the form of collection of niche content or interactive live webcam shows. Their competitive advantage lies in their ability to harness a base of consumers (either free users or paying customers), sometimes to form a community that will be tied to the service as the users provide feedback on the quality of the content.

Third, we identify today's market leaders, which were initially not particularly focused on pornography but on communication and information technology. Developed by IT companies, websites such as Porn Hub and You Porn have a competitive advantage in that they are able to process an enormous amount of data. Although they have joined the adult market recently, they have quickly become dominant by offering a massive stock of free videos to the users.

\section{The growing role of user communities}

The former analysis neglects the increasing role of a fourth actor, namely user communities. The role of users in the innovation process in creative industries is increasingly acknowledged (von Hippel, 2005). For instance, Burger-Helmchen and Cohendet (2011) studied their role as co-developers in the videogame industry and Dalle and Jullien (2003) and Von Hippel (2001) amongst others investigated open source users-developers.

In the case of online pornography, users have been exchanging images and links from the beginning of the Internet in the 1990s (Mowlabocus, 2015). With the advent of the web 2.0 and the evolution of bandwidth, they have been able to share much more in terms of content format and weight. They can also participate (more or less consciously) in providing data on their own tastes while surfing on pornographic tubes (e.g. through page trackers). Users also benefit from other users' inputs through the aggregation of ratings and user feedbacks

8. Annie Sprinkle performed The Public Cervix Announcement (1990) where the audience could watch a close-up of her cervix by staring through a speculum inserted in her vagina, in order to inform the public about the female anatomy and "lift that veil of ignorance" (http://anniesprinkle.org/a-public-cervix-anouncement/).

9. Translated from Borghi, 2013, p.29. 


\begin{tabular}{|l|l|l|l|}
\hline \multicolumn{5}{|c}{ Actors in the online adult entertainment industry } \\
\hline & Big players: new (“tubes") & Big players: historic le.g. Playboy, Dorcel) & Entrepreneurs (photo blogs, webcams) \\
\hline Strategy & Aggressive marketing & Diversification and branding & $\begin{array}{l}\text { Niche market, extremely personalized } \\
\text { product }\end{array}$ \\
\hline $\begin{array}{l}\text { Revenue } \\
\text { stream }\end{array}$ & Ad banners, freemium offers & Unlimited video streaming & Tips, donation, exclusive content \\
\hline Service & Abundance of content & $\begin{array}{l}\text { Convenience and quality, interactivity and } \\
\text { curated content, niche content }\end{array}$ & $\begin{array}{l}\text { Interactivity, curated content, niche } \\
\text { content }\end{array}$ \\
\hline Resources & Free content and bandwidth & Brand image, capital & $\begin{array}{l}\text { Low cost video material and location, a } \\
\text { community (loyal, providing feedback) }\end{array}$ \\
\hline Partners & $\begin{array}{l}\text { Publicity firms (specialized in } \\
\text { banners) }\end{array}$ & $\begin{array}{l}\text { Mainstream distributors and broadcasters } \\
\text { (TV Pay-per view, merchandising, etc.) }\end{array}$ & $\begin{array}{l}\text { Personal content aggregators (e.g. } \\
\text { Tumblr), blogs, webcam platforms }\end{array}$ \\
\hline
\end{tabular}

which, when taken into account, should result in a better service for all the users. From the early days of online pornography to the present, the involvement of users in the distribution of contents via peer-to-peer protocols has also been fundamental to the development of both distribution services and to the diversification of the content and the ease of its access.

In order to understand the importance and the role of user communities in the case of online pornographic content production, we have to understand the dynamics of creation in the adult industry. To do so, we look into the reasons why pornographic content is produced and how such a production is sustainable.

\section{The dynamics of creation in the adult industry}

Why should a pornographer or anyone contribute to the economics of pornography? Contemporary porn production, which is often consumed in the form of short unscripted explicit scenes, requires a camera and at least one performer. The production of pornographic content and its commercial appropriation usually require both material and personal investment and have consequences in both areas too, so that the incentives to take part in these two activities arguably need to be stronger. In fact, even though the material costs of producing a video are very low, the high substitutability of pornographic content raises both the costs of advertising (differentiation is an uphill battle) and the practical unlikelihood of exploiting the content (due to IP enforcement failure). Moreover, the social stigma borne by pornographers and sex performers can deter newcomers from joining the industry. At best, the adult industry professionals are considered second-class cinematographers (Trachman, 2013).

As adult content is primarily the depiction of a fantasy, we can argue that one reason why one would take part in creating pornography, apart from the potential market opportunities, is to see their or someone else's desire come to life. Darling (2014) lists possible extrinsic incentives to continue production by explaining the new sources of revenue in the adult industry. Extrinsic incentives relate to rational or objective evaluation of the outcome of an action. In our case, creating adult content potentially enables a producer to sell products or new services profitably, for example by targeting a niche market. We argue that the incentives for the contributors to produce pornography (firms and users) also have an important intrinsic part (e.g. see one's fantasy played out in a video).

Intrinsic incentives concern the individual's subjective motivations. In other words, they represent the meaning each person attaches to a task. In Trachman's study (2013) many of the interviewed pornographers reported being motivated by both types of incentives: they have the skills to film and produce content that the consumers are looking for, and accordingly do it to showcase their technical skills (Dalle and Jullien, 2003). At the same time, many of them joined the business as a hobby, out of curiosity, lust or as an extension of their social life (e.g. being in swingers' circles). Looking at amateur content, we can consider for example the incentives to produce pornographic self-portraits on gay dating sites, which have been considered to be motivated by many intrinsic justifications such as exhibitionism, but may increase one's sense of belonging to the gay community with its codes (Race, 2014) and in particular its pornographic imagery. ${ }^{10}$

Speaking of community, collective involvement in making online content is facilitated by digital tools and has become commonplace. However, the problem with collective production, to put it simply, is the problem of free-riding - benefiting from a product without contributing whereas others do, resulting in the depletion of the common resource. Nevertheless, in other cases of low IP regimes (Dalle and Jullien, 2003; Loshin, 2007), collectively built resources have been protected thanks to what Elinor Ostrom called "self-governing forms of collective action" (1990, p.25). These operate on the conditions that a precise objective has been set and that the group is tightly knit, for instance with integrated social norms or by excluding outsiders.

Examples of collective action that we can find in the adult industry may concern a certain sexual practice or fetish, or even promote a political view (e.g. anti-censorship and pro-porn feminists). In this context, we believe that the creation, sharing and appropriation of pornographic content is motivated by intrinsic incentives, as these groups are not primarily interested in the market output of their contribution, but rather on their impact as a collective or on the community itself. 
User communities as a means to produce, share, and monetize alternative pornography

Communities in the adult sector act as means to coordinate individual online contributions to diverse common resources. Thus, heterogeneous community members can improve their own skills and knowledge by communicating with each other using the common repertory of resources which itself grows along with the practice (Cohendet et al., 2006). These members are drawn to a practice (to form an epistemic community), to a person (to form a fandom), to a project, to an artistic movement and/or to a political cause and do not generally participate homogeneously to the creation and appropriation of adult content: their contributions depend on their skills and incentives. Such users participate in the making, advertising and protection of pornographic content because they want to see their practice illustrated for masturbatory purposes, exhibitionism or for the visibility of a practice. Numerous fetish communities, then, self-produce or advertise very specific content that is tailored for the community for these reasons. Besides, activist communities have also strong intrinsic motivations for self-producing and promoting their own pornography. Many initiatives in so-called "ethical pornography" for instance seek to improve working conditions for porn professionals.

In this context, we identified three specialized contributions or tasks: producing, sharing and monetizing (see table 2). Producing is the action of finding means to create and enable the creation of a pornographic content. This content may take different forms: from the script to the final product (film or other media) communities are involved in the creative process as a source of ideas (a practice called "crowdsourcing"), of funding (also known as "crowdfunding"), or by sharing their practical skills, expertise, knowledge or opinion. Sharing is the action of assisting in the diffusion of content, for instance by recommending it to a friend or a fellow community member. Sharing, then, contributes to adding a symbolic (non monetary) value to the content by validating its quality. Monetizing consists in enabling one creator to generate monetary benefits from a piece of content or any product or pornographic creation. Each of these tasks can be carried out by several community members, depending on their competencies, so that different types of knowledge and pornographic content are produced collectively by the communities.

Some creative community members produce original content although the output is marginal. Content may exist in the form of a live cam show or erotic stories. Such user-generated adult content is made to be seen either by strangers when the content is freely accessible (or by a given community when the content is reserved to members of a website). The web 2.0 sparked a flurry of content platforms such as those hosting user-generated content (e.g. Instagram, Youtube), "echoing services" where users collect content from other websites like Pinterest (Mowlabocus, 2015, p.227) or social networks like Facebook. These digital tools allow the basic user to gather content actively and publicize it more easily. However, not all of them allow adult content: for instance, Facebook and Instagram do not whereas Twitter does. As a consequence, one will most likely find virtual communities (composed of both professionals and amateurs) producing collections of copyrighted and sometimes original adult content on relatively open platforms (Twitter, Tumblr) or specialized platforms (Pinsex, Uplust). Editorial choices in these collections validate some contents in the eyes of the community it addresses (Dubois, 2014). Other members have the possibility to support this editorial choice as they leave their opinion in the comments sections of collection blogs. Some of these commentators go as far as providing own criticism on different types of content making them experts in the fields; some are already experts. In this way, communities enable the selection and the promotion of content when they particularly appreciate it or when it suits their or other communities' tastes. It also happens that members "test" content, by consuming it and then sharing their experience, which can be trusted to some extent as some of the testers partner up with brands to promote specific content. Thus, testers may be the first users and influencers within or outside their communities.

Communities can also disseminate content by sharing links on forums or hosting content on their own websites. However, this role is not often carried out by user communities, as hosting can sometimes be very costly. When compared to tube sites (free content aggregators), which are capable of hosting

\begin{tabular}{|l|l|l|l|}
\hline \multicolumn{2}{|c|}{ Role of communities in the collective production of pornographic content } \\
\hline \multirow{2}{*}{ What? } & How? & Examples \\
\hline \multirow{2}{*}{ Production } & $\begin{array}{l}\text { Production of original } \\
\text { content }\end{array}$ & Low production costs & $\begin{array}{l}\text { Pro-porn feminists, queer, ethical, alternative porn } \\
\text { platforms (ex. PinkLabel.tv, XConfessions.com) }\end{array}$ \\
\cline { 2 - 4 } & Production of collections & $\begin{array}{l}\text { Democratization of digital } \\
\text { aggregation and sharing tools }\end{array}$ & $\begin{array}{l}\text { Erotic online photo collections (Tumblr pages), selfie } \\
\text { posting application (Uplust, former "Pornstagram") }\end{array}$ \\
\hline $\begin{array}{l}\text { Sharing (moral } \\
\text { appropriation) }\end{array}$ & Distribution & $\begin{array}{l}\text { Hosting content (costly), sharing } \\
\text { links on forums (very low cost) }\end{array}$ & $\begin{array}{l}\text { Collective for niche films, specific practice forums } \\
\text { lex. Fetlife), self-distribution }\end{array}$ \\
\cline { 2 - 4 } & $\begin{array}{l}\text { Testing, selection, valida- } \\
\text { tion, promotion, influence }\end{array}$ & $\begin{array}{l}\text { Individual and collective } \\
\text { comments and ratings, reviews }\end{array}$ & $\begin{array}{l}\text { Blogs, any 2.0 platforms: with the possibility to } \\
\text { interact with other individuals }\end{array}$ \\
\hline $\begin{array}{l}\text { Monetization } \\
\text { (revenue } \\
\text { appropriation) }\end{array}$ & $\begin{array}{l}\text { Enabling a project or } \\
\text { allowing for project to be } \\
\text { profitable }\end{array}$ & $\begin{array}{l}\text { A sum of individual financial } \\
\text { contribution }\end{array}$ & $\begin{array}{l}\text { Crowdfunding, donation (ex. piggybankgirls.com), } \\
\text { membership fees }\end{array}$ \\
\hline
\end{tabular}


significantly more content, the impact of smaller scale diffusion by the communities' platforms is negligible.

To summarize, online communities act as influencers, distributors, and to a smaller extent as producers (Table 2). This can be explained, on the one hand, by the restrictive mainstream IP regimes that are hostile to fan-made creations (as opposed to alternative regimes such as Creative Commons ${ }^{11}$ or Copyleft ${ }^{12}$ ), and on the other hand, by the lack of returns due to the low number of members in certain communities (not to mention of members willing to pay). Moreover, we might argue that as participation in the making and promotion of community porn is a voluntary, and often amateur practice, the participants' lack of professional skills and the fear of social stigma discourage the creation of content, let alone commercial content. Nevertheless, by taking up these roles, communities absorb sunk costs for creative research and development.

\section{Empirical analysis}

In order to empirically explore the role of online communities in the production and appropriation of content we consider the case of one specific festival which interacts with several communities linked to the alt-porn movement. Case studies are important in order to collect qualitative insights about exploratory research (Yin, 1994, Eisenhardt, 1989). In the case of the online porn industry they have been carried out by different authors on pornographic labor (Trachman, 2014) and on online communities providing digital pornographic content through picture blogging (Dubois, 2014) or live-caming (Mowlabocus, 2015). The two latter studies tackled both mainstream and alternative pornography whereas Trachman (2014) concentrated on the French mainstream pornographic industry.

\section{Methodology and data collection}

Collecting data on the pornographic industry is not an easy task (Damian-Gaillard, 2012). It is difficult because reliable quantitative data is rare, and if it exists, it becomes quickly outdated in the Internet era, as data appears and changes at an exponential rate. Second, qualitative data is accessible and relevant when studying communities, but it takes time to gain the interviewees' trust.

Our first task was hence to collect second-hand data in order to grasp the industry's challenges and trends but also to reach a better understanding of the alternative pornography movement. We carried out a review of transdisciplinary academic literature from American and European porn studies, industry websites and blogs (e.g. xbiz, hot video, letagparfait. com) pointing at feminist or queer pornography as an emerging niche and even a potential competitor on the adult market. At the same time, exploratory interviews with mainstream porn consumers and alt-porn community members were conducted in order to refine the distinction between alternative and mainstream pornography.
Finally, we were able to carry out interviews at multidisciplinary festival "La fête du slip" (meaning literally "Underpants Fest”) held in Lausanne, Switzerland in March 2016. According to its manifesto, the event celebrates sexuality as a part of a "sexpositive" movement. It also includes an international competition for short pornographic films. Organized by the eponymous association, led and created in 2013 by brother and sister Stéphane and Viviane Morey, the festival committee is composed of health professionals, academics and arts professionals.

We chose the "La fête du slip" festival for its deliberate effort to stand out from other events celebrating erotica, pornography and the sex industry, ${ }^{13}$ categorized as "mainstream" by professionals but also by academics, particularly in gender (Borghi, 2013) or porn studies (Vörös, 2015). We therefore hypothesized that the presence of communities is higher in such a festival (thereafter called FDS) as it is explicitly artistic and politically engaged as opposed to more mainstream, catch-all events. In addition, the festival openly welcomes researchers and several people from the academia participated in the previous editions.

Interviews were conducted with both professionals and amateurs, with different roles in the industry as distributors, directors, actors but also consumers. A number of these individuals are part of a community whose activity contributes to the appropriation of pornographic content by producing, distributing and advertising it. We first wanted to know who is taking care of pornographic production in the alt-porn subgenre. Then, we looked at the other roles that community members may take upon and the way they describe the community dynamics both online and offline.

With this analytical framework and case context in mind, we recorded interviews with seven artists and three professionals in the adult entertainment industry for an average length of 35 minutes per person during the festival in March 2016. The semidirective interviews were conducted in French and English. They focused on incentives to produce and consume pornographic content, but also on the presence (or not) of communities at the festival. We started each interview by asking the interviewee to introduce themselves. For some of them, we re-stated the objectives of our study, which we had briefly presented quickly at the professionals' meeting organized by the festival for networking purposes. We finished the interviews by asking about their future projects. We collected contacts to send follow-up questions, find other potential interviewees, and keep in touch with the interviewees after the festival. We also interviewed ten consumers on their consumption of digital content and of pornography in general (see Table 3).

\section{Results}

Most community members are consumers before being producers or distributors. However, we noted that consumer surveys aimed at gathering quantitative data are difficult to carry out in a one-to-one questionnaire, as consumers of pornography do

11. Creative Commons licenses allow to grant certain copyright permissions on creative content in contrast to the traditional "all rights reserved" copyright principle (https: //creativecommons.org/).

12. Introduced with the GPL license, Copyleft licenses allow everyone to modify, copy and distribute the software only if any changes made on the software are protected by the same principle (Pénin, 2011).

13. Such as the French "salons de l'érotisme" (erotic fairs), or award ceremonies for professionals in the sector like the "Hots d'or" in France or the AVN Awards in the USA. 


\begin{tabular}{|c|c|c|}
\hline \multicolumn{3}{|c|}{$\begin{array}{c}\text { TABLE } 3 \\
\text { Summary of the interviews }\end{array}$} \\
\hline & Profile & Duration \\
\hline \multirow[t]{2}{*}{$\begin{array}{l}\text { Exploratory } \\
\text { interviews }\end{array}$} & 4 male mainstream porn users & $\begin{array}{l}\text { - online: } 20 \text { minutes } \\
\text { - face-to-face: } 1 \text { hour } \\
\text { In French and in English }\end{array}$ \\
\hline & 1 female niche porn user & 2 hours 41 minutes, face-to-face, recorded, in French \\
\hline \multirow{5}{*}{$\begin{array}{l}\text { Festival interviews - } \\
\text { producers / artists }\end{array}$} & Pornographer 1 & 44 minutes, face-to-face, recorded \\
\hline & Pornographer 2 & 55 minutes, face-to-face, recorded \\
\hline & $\begin{array}{l}\text { Pornographer } 3 \\
\text { Pornographer } 4\end{array}$ & 38 minutes, face-to-face, recorded \\
\hline & $\begin{array}{l}\text { Pornographer } 5 \\
\text { Pornographer } 6\end{array}$ & 1 hour 14 minutes, face-to-face, recorded \\
\hline & Pornographer 7 & 35 minutes, face-to-face, recorded \\
\hline \multirow{3}{*}{$\begin{array}{l}\text { Festival interviews - } \\
\text { professionals }\end{array}$} & Librarian & 45 minutes, face-to-face, recorded \\
\hline & Journalist & 24 minutes, face-to-face, recorded \\
\hline & Retailer (toxine free condoms) & 29 minutes, face-to-face, recorded \\
\hline \multirow{2}{*}{$\begin{array}{l}\text { Festival interviews - } \\
\text { consumers }\end{array}$} & Consumer 1 to 7 , Interviewer 1 , directed & notes, face-to-face \\
\hline & Consumer 8 to 10 , Interviewer 2, semi-exploratory & notes, face-to-face \\
\hline
\end{tabular}

\begin{tabular}{|c|c|c|}
\hline \multicolumn{3}{|r|}{$\begin{array}{l}\text { TABLE } 4 \\
\text { Summary of the results }\end{array}$} \\
\hline What? & To what extent? & FDS examples \\
\hline $\begin{array}{l}\text { Production of } \\
\text { original online } \\
\text { content }\end{array}$ & $\begin{array}{l}\text { Rare, difficult to } \\
\text { access }\end{array}$ & $\begin{array}{l}\text { Most of the interviewed producers do not make a living out of their content. Pornography } \\
\text { is not their principal source of revenue: in this case, then, supply is marginal. Most of their } \\
\text { content is accessible through paid and minor online video platforms. }\end{array}$ \\
\hline $\begin{array}{l}\text { Production of } \\
\text { online collections }\end{array}$ & $\begin{array}{l}\text { Relatively } \\
\text { commonplace }\end{array}$ & $\begin{array}{l}\text { Blogging was producer 1's first project in alt-porn, allowing her to create and foster a } \\
\text { community around her. }\end{array}$ \\
\hline $\begin{array}{l}\text { Distribution } \\
\text { (offline and online) }\end{array}$ & Rare & $\begin{array}{l}\text { Content can be disseminated upon request to the director for a USB stick transfer or by } \\
\text { sharing links to an online locker. }\end{array}$ \\
\hline $\begin{array}{l}\text { Validation } \\
\text { (offline and online) }\end{array}$ & Commonplace & $\begin{array}{l}\text { The FDS itself is an example where a community selects, showcases and rewards content. } \\
\text { Validation occurs in the form of feedback more than recommendation. }\end{array}$ \\
\hline Monetizing & $\begin{array}{l}\text { Rare, associated } \\
\text { with validation }\end{array}$ & $\begin{array}{l}\text { When the consumers are willing to pay, they do so in order to express support to the ethics } \\
\text { of post-porn, a brand or a performer }\end{array}$ \\
\hline
\end{tabular}

not reveal their preferences or practices easily. Even when asked about the reasons why they do not consume pornographic content, interviewees are generally reluctant to answer. The more detailed answers were actually given by the artists who both produce and consume pornography. We believe this is the case because these individuals who actively participate in the making of porn, belong to several communities (professional, activists or of sexual practice). Interestingly, these multi-community members, who gave us the richer answers, are those most prone to being more involved in the production, diffusion and appropriation of pornography, both in terms of volume and of benefits to the community. Eventually, the interviews results illustrate the typology of roles detailed in table 2 . We conclude that in alt-pornography, all roles are performed but on different scales, as summarized in table 4 .

\section{Production of content}

According to interviewed consumers, there is a production of original content by communities but it is simply not as accessible as mainstream content. In the interviews, alt-pornographers described different incentives for creation, most of which were intrinsic. For two of them, the sexual excitement arising from making the films motivated their entry in the world of pornography. The others reported using sexuality as a subject more than an end. Having a background in photography, cinema or visual art, they see representing explicit sexuality as a way to express themselves artistically: "I make porn because I find sex is my language within art", says producer 7 .

Interestingly, all the interviewees expressed their interest in making a living out of their pornographic activities, as producer 2 did:

"I discovered myself, even sexually since I was doing porn, it is important for me to show my ideas through porn, what is my vision of sexuality. At the same time I want to make a job of it. Besides my passion to communicate things, it's the money."

The difficult transition from an intrinsically motivated production to an extrinsically motivated one is most likely due to the 
lack of entrepreneurial skills. Remarkably, all the interviewees were unfamiliar with appropriation and monetization issues except for one, who happens to be the only one who successfully became a full-time professional pornographer.

\section{Sharing content}

The interviews suggest that sharing happens online, offline, legally, illegally, formally (in workshops, conferences) and informally (by talking, networking). Accordingly we expected interviewees to have mainly a role of diffusion as it is easy, virtually costless (when it consists in sharing links and digital content) and integrated in social digital habits (Mowlabocus, 2015). Actually, interviewees do not seem to use social media to exchange or share content. However, they seem to use it as a rating and feedback tool for the platform, the performer or anyone at the other end of the video. This can be explained by the censorship of mainstream social media, and maybe to some extent by the low use of social media by the interviewees for recommending content, let alone of a pornographic nature, and the social stigma borne by people who admit to watching porn, even within a community. Some of the consumers (in particular producers 3 and 5) prefer attending community gatherings (such as festivals) to discover new contents and share their own.

\section{Monetization of content}

Monetization is also rare in those communities where exchanges are most of the time symbolic. Moreover, revenue appropriation is often not significant and does not always cover costs. Some consumers say they pay for porn but the supply is rare. Most of the time, consumers (even of niche content) find it very hard to conceive that they should spend money on pornographic content. Most consumers find content to their liking (though they may not necessarily appreciate it esthetically or conceptually) on free content aggregators. Those who do not go on tubes because they have specific tastes (for feminist/alternative content principally) tend to either watch illegally, pay or refrain from consuming at all. Those who watch illegally stated that they would pay if they had the money, illustrating the possible use of piracy as a means for the consumers to sample future purchases. Those who pay often are loyal to one artist or brand. For them, paying is a mark of appreciation but also a political gesture of economic support to feminist/post-porn as a market alternative.

We therefore conclude from the interviews that communities (both online and offline) have more of a role in the creativity of the sector (by adding symbolic value) than in the monetization of new content.

\section{Conclusion}

The aim of this paper was to provide an introduction to the role of user communities in the production and distribution of alternative pornographic content. The online adult entertainment sector is another case of low IP regime, thus preventing content providers to sell directly copyrighted content and forcing them to switch to alternative business models. We therefore explored how online user communities help to partly solve this appropriation failure and enabling content providers to recoup part of their initial investments by carrying out three functions: producing content, increasing the symbolic value (what we also called "sharing") and appropriating revenue of pornographic content ("monetizing").

We showed that due to the intrinsic part of users' motivation in particular, these communities can play a significant role in the production and the distribution of pornographic content.

In other words, although online user communities do not have the power to fully solve the problem of appropriation failure in the adult entertainment sector, in particular because they do not systematically help to produce original content, we argue that they are part of the solution. Their role complements developments already documented in the literature such as the focus on user-friendly and user-centered services. They reinforce the efficacy of those strategies. Communities can significantly increase the value of this content by offering additional, complementary services such as more interactivity, rankings, prescriptions, advertising, feedback and diffusion.

Our paper therefore has important implications for businesses and content producers. In most sectors, the digital era has revealed the importance of social networks and of user feedback in the marketing strategies of firms, but this may be even more crucial in a sector with a low IP regime such as online pornography. Producers aiming to enhance interactions and improve access can find valuable partners in online communities. It is therefore critical for them to be capable of harnessing the power of those communities.

Yet, creative and virtual communities are often not motivated by extrinsic factors. Overall, business knowledge (for monetization and appropriation) does not seem to be a priority in the subgenre even though it is bound to be a profitable niche. Knowledge building tends to be more focused on the discovery of new contents and ways to produce sexually stimulating content. As a result, their financial viability may be in danger when they are not managed with sustainability as an objective. Moreover, their lack of business connections (e.g. distribution channels and advertising), which are not encouraged by the marginal traffic that niches generate, is often a reason for the short life span of community creative initiatives. As Amin and Roberts (2008) suggest, these short-lived communities may need support from formal institutions and firms to sustain their creative potential and innovative energy.

Interestingly, a few recent studies have established means for companies to harness the communities' creative potential (for example, Burger-Helmchen and Cohendet, 2011). In our case, communities can help complement the strategy identified by Darling, namely providing a customized user experience. By providing feedback (in the form of testing and prescription) communities help the companies to evaluate and structure the market, just like von Hippel's lead users (2005). The communities, in particular alt-porn, as they encourage repeated online and offline interactions and foster symbolic exchanges, can heighten interactivity and a sense of belonging. A company, especially one that operates online, can consequently improve user experience when it is capable of integrating social dynamics in its business model (Pénard and Suire, 2008). One way to do so might be to sponsor communities and provide them with some resources, like Dorcel (French leader in pornography) did when they decided to invest in Uplust, an explicit photo sharing and social networking app. 
However, as they look for the communities' support, firms should remember to keep the communities alive as a creative fringe and remain aware of both their intrinsic and extrinsic motivations. Changing the spirit or the goal of the community can kill the community as a creative pool. The example of the Suicide Girls community illustrates this phenomenon: as the website was gradually monetized and the models and photographs were poorly paid, the community felt betrayed and early users of the website, which used to be free, preferred switching to other free and community-fed picture aggregators.

\section{References}

Amin, Ash; Roberts, Joanne (2008). "Knowing in action: Beyond communities of practice", Research Policy, vol. 37, $\mathrm{n}^{\circ} 2$, p. 353-369.

Boldrin, Michele; Levine, David K. (2008). Against Intellectual Monopoly, Chapter 2, Cambridge University Press, p. 40-42.

Borghi, Rachele (2013). "Post-Porn”, Rue Descartes, Vol. 3, n 79, p. 29-41.

Burger-Helmchen, Thierry; Cohendet, Patrick (2011). "User Communities and Social Software in the Video Game Industry", Long Range Planning, vol. 44, n 5-6, p. 317-343.

Cohendet, Patrick; Créplet, Frédéric; Dupouët, Olivier (2003). "Innovation organisationnelle, communautés de pratique et communautés épistémiques: le cas de Linux”, Revue française de gestion, ${ }^{\circ} 146$, p. 99-121.

Cohendet, Patrick; Creplet, Frédéric; Dupouët, Olivier (2006). La gestion des connaissances: Firmes et communautés de savoir, Economica, Collection Gestion, Paris, 202 p.

DAlle, Jean-Michel; Jullien, Nicolas (2003). "Libre" Software: Turning Fads into Institutions”, Research Policy, vol. 32, nº 1, p. 1-11.

Damian-Gaillard, Béatrice (2012). "Entretiens avec des producteurs de la presse pornographique: Des rencontres semées d'embûches...", Sur le journalisme, About journalism, Sobre jornalismo, vol. $1, \mathrm{n}^{\circ} 1$.

Darling, Kate (2014). "IP Without IP? A Study of the Online Adult Entertainment Industry”, Stanford Technology Law Review, vol. 17, p. 709.

Di Stefano, Giada; King, Andrew; Verona, Gianmario (2013). "Hell's kitchen: sanctioning violations of norms of knowledge use in gourmet cuisine", Working paper HEC Paris.

Dubois, François-Ronan (2014). "Les blogs, de la photographie de mode à la photographie pornographique", Questions de communication, $\mathrm{n}^{\circ} 26$, p. 153-163.

EISEnhaRDT, Kathleen M. (1989). Building Theories from Case Study Research, The Academy of Management Review, vol. 14, $\mathrm{n}^{\circ} 4$, p. 532-550.

FAUCHART, Emmanuelle; von Hippel, Eric (2008). "Norms based IP systems: the case of French chefs", Organization Science, vol. $19, \mathrm{n}^{\circ} 2$, p. 187-201.
To conclude, this paper is only a first step towards the understanding of the role of user communities as a means to support new business models in online pornography. Our work obviously needs to be deepened by exploring, among others, cases other than alternative porn. It will also be necessary to need to further analyze whether the elements observed in this study on the case of alternative porn can apply to mainstream porn (or to other sectors confronted to digitization).

LAVE, Jean; Wenger, Etienne (1991). Situated Learning: Legitimate Peripheral Participation, Cambridge, Cambridge University Press, 138 p.

Lerner, Josh; Tirole, Jean (2001). “The Open Source Movement: Key Research Questions”, European Economic Review, vol. 45, n $4-6$, p. 819-826.

Loshin, Jacob (2007). Secrets Revealed: How Magicians Protect Intellectual Property without Law, Available at SSRN: http://ssrn. com/abstract $=1005564$

Mowlabocus, Sharif (2015). "Porno 2.0? La centralité de l'utilisateur dans la nouvelle industrie du porno en ligne”, in VÖRÖS, Florian (ed.), Cultures pornographiques: anthologie des porn studies, Paris, Éditions Amsterdam, p. 225-248.

Oliar, Dotan; Sprigman, Christopher J. (2008). “There's No Free Laugh (Anymore): The Emergence of Intellectual Property Norms and the Transformation of Stand-Up Comedy", Virginia Law Review, vol. 94, $\mathrm{n}^{\circ} 8$.

Ostrom, Elinor (1990). "Governing the Commons: the Evolution of Institutions for Collective Action”, Cambridge, Cambridge University Press, 298 p.

PÉNARD, Thierry; Suire, Raphaël (2008). "Economie de l'Internet une économie d'interactions sociales”, Revue française d'économie, vol. $22, \mathrm{n}^{\circ} 3$, p. 151-187.

PÉnIN, Julien (2011). "Open source innovation: Towards a generalization of the open source model beyond software", Revue d'économie industrielle, $\mathrm{n}^{\circ} 136$, p. 65-88.

Perzanowski, Aaron. (2013). “Tattoos \& IP Norms”, Minnesota Law Review, vol. 98, p. 511.

RACE, Kane (2014). "Looking to play? Les technologies de drague en ligne dans la vie gay”, in QUEMENER, Nelly; VÖRÖS, Florian (Eds.), Poli - Politique de l'image, n 9, p. 50-61.

Raustiala, Kal; Sprigman, Christopher J. (2012). The knockoff Economy: How Imitation Sparks Innovation, Oxford, Oxford University Press, $280 \mathrm{p}$.

Raustiala, Kal; Sprigman, Christopher J. (2006). “The piracy paradox: innovation and intellectual property in fashion design", Virginia Law Review, vol. 92, n 8, p. 1687-1777. 
Trachman, Mathieu. (2013). Le travail Pornographique, Enquête sur la production des fantasmes, Paris, La Découverte, coll. "Genre \& Sexualité", 286 p.

Von Hippel, Erich (2001). “Innovation by user communities: Learning from open-source software”, MIT Sloan Management Review, vol. $42, \mathrm{n}^{\circ} 4$, p. $82-86$.

VON HiPPEL, Erich (2005). “Democratizing innovation: The evolving phenomenon of user innovation", Management Review Quarterly, vol. $55, \mathrm{n}^{\circ} 1$, p. 63-78.

VöRös, Florian (ed.) (2015). Cultures pornographiques: anthologie des porn studies. Paris, Editions Amsterdam, $320 \mathrm{p}$.

YIN, Robert K. (1994). Case study research: Design and methods (2nd ed.). Newbury Park, CA: Sage Publications.

Zook, Matthew (2003). "Underground globalization: mapping the space of flows of the Internet adult industry", Environment and Planning A, vol. 35, p. 1261-1286. 